\title{
Translating in an emerging language policy: Tampere city council 1875-87
}

\author{
Kaisa Koskinen
}

\section{Introduction}

Research on multilingualism and language policies has established some basic tenets that this chapter builds on. First, the coexistence of more than one language always entails some translatorial movement between languages, creating a translation space (Cronin 2006: 68). This translatorial movement can take the form of institutionalized practices or operate through the micro-decisions made in everyday life (Wolf 2012). Second, whenever we make decisions about how to deal with the multiplicity of languages, we all engage in doing language policy (Spolsky 2004). That is, language policy need not be official or even spelled out; it can also emerge incrementally from practices. Third, language policies always have translational repercussions, whether or not they explicitly aim to ban, control or promote translating or interpreting (Grin 2010; Meylaerts 2013).

The object of this chapter is the gradual process of institutionalization, that is, the process towards an established language policy with its concomitant translation practices, in the context of local governance in nineteenth-century Finland. Following Spolsky (2004: 39), this chapter is based on the understanding that language policy is realized at three levels: in addition to language planning and regulations, it also plays out through language ideologies and language attitudes as well as through everyday micro-decisions over language choice. In a way, the most fundamental level, the sine qua non of language policy, is that of the everyday micro-level of actual practices: language policy that is not implemented in practice remains a dead letter. The next level is that of language planning, which is most explicitly realized through providing a legislative 
framework. The outer circle of attitudes and language ideologies forms the cultural and ideological context that frames the other two levels.

This chapter traces how these three levels of language policy and translation interact in one local context of municipal government, the late-nineteenth-century Tampere, Finland. More specifically, I focus on the formative years during and immediately after the new legislation of local governance issued in 1873 led to a reorganization of local institutions everywhere in the Grand-Duchy of Finland. The nexus of my analysis is the gradual development of the language policy of the newly established Tampere city council, starting from its first meeting in 1875 and continuing until 1886 when the language policy issue was settled. The longitudinal aspect has been selected to emphasize the incremental nature of governance practices. Michel Foucault (1978/2007: 108-9; see also Koskinen 2014a) discusses the gradual process of governmentalization, that is, the development of particular governmental apparatuses and the establishment of an ensemble of 'institutions, procedures, analyses and reflections, calculations and tactics' of governing. Here, my aim is to trace the procedures, tactics and calculations related to language and translation policies in the governmentalization of one municipal institution. This aim has been operationalized through a selection of four key moments during the time span in question. The analysis of these 'dense moments' provides a longitudinal case study of the three levels of language policy in action through a cross-examination of three data sets: the minutes of the city council, local media of the time and the relevant legislation.

As across Europe, the nineteenth century was a time of national revival in Finland, and the language issue - that is, advancing the case of Finnish - was a central element of this revival. Administration at both national and municipal level had been almost exclusively Swedish, but new language legislation began to gradually improve the status of Finnish during the latter half of the nineteenth century. This new legal framework and the evolving language attitudes set the background for new language practices in governing institutions. In this political and cultural climate, the new municipal councils in dominantly Finnish-speaking areas such as Tampere became instrumental in developing a more democratic language regime at the local level. For my purposes, the 'carte blanche' situation of the council, as a newly established institution only beginning to sort out its language practices, provides a microcosm in which to observe the emerging and developing relations between language planning, language ideology and translation practices.

The micro-level practices during the first year of the new Tampere council, and their effects on the language planning level, have been studied in close detail 
earlier (Koskinen 2017 and forthcoming). This chapter takes a more longitudinal running head approach and also takes stock of media discussions, contrasting the prevailing language ideologies as expressed in local newspapers with the language planning efforts in the council. The chapter unfolds as follows: Section 2 illuminates the context of my data, looking into the characteristics of Tampere and in particular its language situation and the language battle between Finnish and Swedish fought not only at the national level but also in local newspapers which provided a platform for expressing and debating language attitudes at the time. Section 3 introduces the new city council and its linguistic set-up. Section 4 describes my data and methodology. The four dense moments are discussed in Section 5, and the results are then contemplated in Section 6.

\section{The context of Tampere}

In the 1870s, Tampere - the Manchester of Finland - was a dynamic and rapidly growing industrial centre, and the third biggest town in Finland, in the then autonomous Grand-Duchy of Russia (1809-1917). ${ }^{1}$ Between 1870 and 1900 Tampere grew threefold in size and fivefold in terms of inhabitants (Vähäpesola 2009a). The Tammerkoski Rapids that run through the city centre powered the new factories that had been set up on both sides. The employment opportunities provided by these factories attracted masses of young Finnish-speaking workers from the surrounding countryside. Tampere had always been dominantly Finnish-speaking, but the industry-led urbanization process further increased the number of Finnish-speakers. ${ }^{2}$ In 1880, 7.4 per cent of the inhabitants were Swedish-speaking, and the percentage went further down to 5.6 per cent in 1900 (Vähäpesola 2009b). The linguistic set-up in the demographics of Tampere included a handful of languages, but the numbers for any other languages, including Russian (twenty-four inhabitants in 1880; Koskinen 2014b), were tiny - approximately 1 per cent of the total population. In spite of its small size, foreigners were an economically and culturally important group, as many of the factory owners, top management and skilled engineers were of foreign origin (mainly German-speakers), and Russian merchants contributed to the bustling economy.

Under Russian rule, the dominance of the Swedish language, and the relative absence of Russian, may appear rather unexpected. But when Tampere (Tammerfors) was first founded in 1779, Finland was under Swedish rule, and Swedish was the language of administration. Finnish, in turn, was the language 
of the peasantry that had only begun to emerge as a written language, largely via translation activities (Paloposki 2007). When Sweden was forced to hand its easternmost regions over to Russia in 1809, the new rulers allowed the Swedish language to continue to dominate in governance. Russian was never widely spoken among the elite groups of Finland, and the Russian rulers originally had little faith in Finnish as a language of administration nor in the Finns' ability for independent governance and sophisticated cultural life. They feared that banning Swedish would have equalled banning legality and civilization. Still, the new rulers also saw supporting the rise of Finnish as a way of severing the ties with Sweden, and over the century a number of legislative steps to advance the use of Finnish were taken (Engman 2009: 230-3).

During the period under study, sovereign rule was gradually giving way to a more democratic form of governance, and the first forerunners of modern political parties were emerging. In this process, the language issue was a dividing factor. Since the 1840s, language attitudes had become an increasingly heated element in the Fennophile 'Fennoman' movement (in the 1890s this radicalization of attitudes led to a split between more radical/liberal and more conservative Fennomans, with repercussions to the political balance because of the loss of unity). It had an equally radicalized counterpart, the 'Svecomans', or suecophiles. In line with Romantic nationalist movements sweeping across Europe, the local Fennomans equated the use of Finnish with patriotism and labelling Swedish as a 'foreign' language. It is not too surprising that some Swedish-speakers felt that their entire identity was at risk. The language issue was, however, divisive also among the Swedish-speakers. Some of them were actually among the most ardent supporters of the case of Finnish, and their contributions were essential for the gradual progress of Finnish.

Tampere was recognized as a hotspot of this radicalization. One can identify various reasons for this development. As opposed to the cultural capitals of Turku (Åbo), Helsinki (Helsingfors) or Viipuri (Vyborg), with their old nobility, cultural and educational institutions and cosmopolitan flair, Tampere was a young, bustling city of Finnish-speaking workers. Its rapid growth, technologization and international contacts must have given the inhabitants a forward-looking sense of progress and modernization. The lack of any national or regional governance institutions in Tampere, and its growing cadre of businessmen, most of whom were Finnish-speaking, resulted in a fairly thin layer of Swedish-speaking higher bourgeoisie upper class in Tampere. The layer was also rapidly getting thinner: in the 1870s, at the beginning of the time span studied here, little less than 10 per cent of the Tampere inhabitants belonged to the upper class; in 1890, the figure 
was less than 1 per cent. At the same time, the bourgeoisie class expanded from 10 to 40 per cent because of the growth of merchants' and artisans' group. By far the biggest group was still the workers: 60 per cent of the inhabitants belonged to this group by 1890 (Vähäpesola 2009c).

Why the case of Finnish would have been felt particularly pressing in Tampere is easy to understand. It is less easy to understand why it led to such heated debates, especially as it is known that many of the few Swedish-speakers were bilingual and supportive of the case of Finnish. The numbers reported earlier indicate that the power balance was rapidly shifting, and the old elite was being challenged by both the growing entrepreneur class and the workers who were getting both more numerous and increasingly restless and empowered by the international workers' movement. This may have felt overwhelming for some, and the language issue was both a concrete issue to take stand on and a symbolic battle of status between groups. At the same time, multilingualism, and the translatoriality it brought forth, was a fact of life in Tampere, and foreign languages were viewed favourably in the press. The local and national linguistic duel was fought between the two local languages only. In spite of compelling numbers, for historical reasons Swedish had the upper hand in Tampere: 'Swedish was the language of power, prestige, and upward social movement, while Finnish was the language of the uneducated masses' (Koskinen 2014b: 191).

Another explanatory factor behind the language conflict is the gradual development of party politics in Finland during the late nineteenth century. Before the birth of the first political parties in the modern sense (a short-lived Liberal party in 1880 and the Finnish Labour Party in 1899), the Finnish and Swedish parties were the first incarnation of representative party-like organizations, and this made linguistic and cultural orientation the most relevant division in the early political battles (Rasila 1984:544), probably leading to strategic aggravation of the expressed attitudes on both sides. Newspapers were the developing modern media of the time, and they provided the main forum for political debates, hence also for the language battle (Rasila 1984: 544-5). It follows that they also played an active role in translatorial and language policy action at the level of attitudes and ideologies. Although newspapers also travelled across Finland, ${ }^{3}$ media was mainly produced and consumed locally. During the time span under study here, also the local newspaper scene of Tampere kept evolving. Tampereen Sanomat ('News form Tampere') had been founded in 1866, with Dr Otto Blåfield and F. E. Jernberg among founders. It was first the only local newspaper, and in spite of being published in Finnish it did not have significant 
active political leanings until after the other Finnish-language paper Aamulehti had been created. It rather operated in an enlightenment spirit and as an official channel for municipal announcements, which were published in both languages (Rasila 1984: 547-8). In the 1879 council elections when language issues were dividing the candidates into two groups for the first time, Tampereen Sanomat remained neutral (ibid.: 548).

Aamulehti ('Morning Paper') was founded at the end of 1881, after a year of turmoil both nationally and locally. It was an explicit mouthpiece for Fennophile ideals, and it promoted Christian morals and democratic values, which in practice meant promoting raising the status of Finnish to the same level with Swedish. Again, F. E. Jernberg was among the founders. The editor in chief F. W. Jalander, who was an ardent Fennoman, himself had no Finnish, and his editorials needed to be translated into Finnish by others. Jalander was replaced in 1884 by Kaarle Viljakainen, a young but already experienced editor with a moderate line in the language issue (Rasila 1984: 548-9). Aamulehti soon established itself as the main newspaper in the area, a position it still holds today. Its strong political stance in language and nationalist issues led to a counter reaction among Swedish-speakers, and Tammerfors Aftonblad ('Evening paper of Tampere') was established in 1882 to support the case of Swedish.

\section{The city council}

The decree on local government issued in 1873 had established an entirely new governance body, the municipal councils. A reform of the municipal institutions was a central phase in modernizing governance in Finland. As a new municipal actor, the councils sidelined the previous powerhouses of local governance, the magistrates, and also created a new division of labour between the church and the state (e.g. in education and welfare). This shift of power created a momentum for introducing new priorities and new practices of governance.

The city council of Tampere began its first operational year in January 1875. The council elections in 1874 were a step towards representative local democracy, but not a giant leap. Tampere had 6,700 registered inhabitants but only 67 votes were cast (Rasila 1984: 569). Most inhabitants did not even have the right to vote. Those in the service of a patron were not seen to be independent enough to cast their vote until after 1917 (Rasila 1984: 582-4). Of the twenty-one new councilmen (independent women were allowed to vote but not to run for office), Dr Otto Blåfield got the most votes and was elected the first chairman. He was 
to become instrumental in establishing bilingual practices in city government (Koskinen 2017: 47).

Through the linguistic set-up of the first council, the previously entirely Swedish-speaking local government now saw a rise in Finnish-speaking councilmen (Koskinen 2017: 47). The council thus needed to overcome linguistic and cultural barriers in its own meetings. As the council began its work, a further barrier was soon found to exist between the at least moderately pro-Finnish council and the adamantly Swedish-speaking magistrate run by the mayor. The most problematic linguistic barrier was still the one between the Swedish administration and the Finnish population. From the outset, the newly elected Finnish-speaking councilmen became operational in the gradual democratizing of local governance, and developing a more democratic language regime was an essential element of it.

\section{Data and method}

In this chapter, the interplay of the three levels of language policy will be charted through an analysis of four 'dense' points where the plot thickens, combining three main sets of data: council minutes, national legislation and debates in the local newspapers. The council as an institutional actor is the nexus of the analysis. Three of the dense points have been identified through looking into the moments when the new city council first debated and established its language policy (and its translation practices) in 1875, and later revised and reassessed this policy in 1878 and in 1886 . The general climate of language attitudes will be charted through analysing the debates in three local newspapers, Tampereen Sanomat (TS; Finnish), Aamulehti (AL; Finnish) and Tammerfors Aftonblad (TA; Swedish) around the dense points identified through other data sets as described earlier. One dense point, year 1881, has been selected also because of its media relevance. During that council election year, heated debates over 'the language issue' raged. At the end of that year Aamulehti was established specifically to support the cause of Finnish, and this in turn led to the founding of Tammerfors Aftonblad in 1882 to support Swedish.

Since language policies are also governed by national legislation, and the council is therefore not entirely free in its language choices, the changing jurisdiction is another relevant factor, and two dense points were also brought on because of the changing legal context $(1875,1881)$. The full timeline of the 


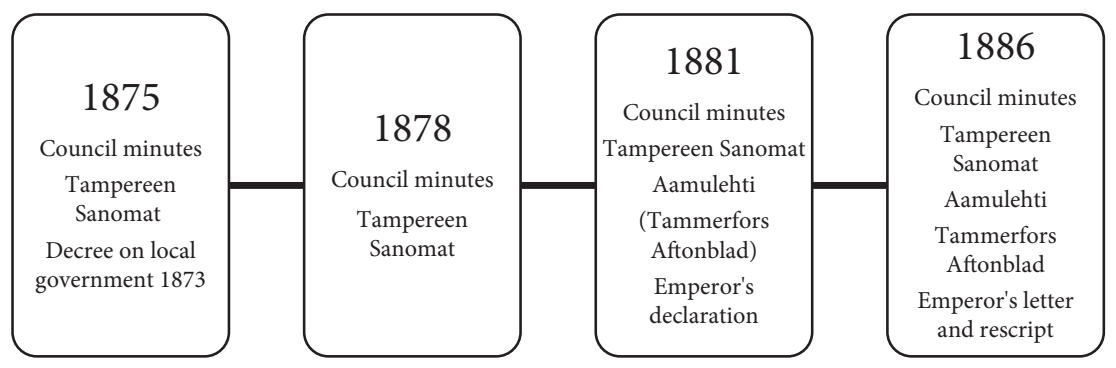

Figure 6.1 Timeline and data sets of the dense points.

dense points, and the data sets for each, is shown in Figure 6.1. All translations from any of these data sets are mine.

Data has been collected from three sources:

1. The minutes of the council have been stored in the Tampere City Archive where they are available on microfilm.

2. The relevant legislation has mainly been downloaded from an open source depository (https://fi.wikisource.org/wiki/Luokka:Kielilainsäädäntö).

3. Newspapers were searched in the national open-access digital archive (https://digi.kansalliskirjasto.fi/sanomalehti/).

In sourcing the minutes, I have relied on both historical research (Rasila 1984) and my own previous research on the emerging translation practice and translation policy (Koskinen 2017 and forthcoming). This has allowed me to economize archive work to the minutes of particular years and also of particular meetings, but this targeted approach may of course have also led to overlooking other potential dense points. Legislation frames the project at both ends. The new degree on local government (Kunnallisasetus 1873) was the motor for the process as it set the scene for the development of the new institution, thus also creating an opening for reforming the municipal language practices. At the other end of the continuum, new regulations can be seen to close this window of local opportunities as an imperial letter of 1886 decreed Finnish to have an equal status with Swedish, and an additional notice given in 1887 set new ground rules for choosing between different language options by ordering that municipal authorities must use the language of the council minutes - in the case of Tampere, Finnish. Legal data has not been sourced in any open-ended manner; the relevant acts and degrees have been hand-picked from the database according to prior knowledge and previous historical research.

Newspaper material is brought in to investigate how the council decisions and practices were rendered and commented on in the press and how the attitudes 
towards language issues and translation evolved. Searching the database was executed in two steps: first, in an open-ended and data-driven manner, with a keyword combination (in Finnish) of 'Tampere', 'languages' and 'council' to identify potential dense points (this led to selecting year 1881 as a dense point) and then with more direct searches to the issues of the three above-mentioned newspapers published before and after relevant dates identified from other data sets. Notably, the first search was executed in Finnish only, which introduces a bias into the research design, giving primacy to the Finnish newspapers, but it needs to be borne in mind that the first Swedish paper in Tampere was only established in 1882 and there is no local Swedish newspaper data prior to that. For 1886 a separate search with a keyword in Swedish ('språk', language) was conducted.

\section{Dense points}

\subsection{Establishing the policy (1875)}

In January 1875, the new council met for the first time. The minutes of the first meeting and from the entire first year of operation have been analysed before from the perspective of translatorial action (Koskinen 2017). I summarize these findings here. Since the councils were a new institution, and prior administration had been Swedish-only, there was no routine and no practices in place to maintain bilingual procedures. Language and translation issues were thus among the first items on the list. In the first meeting on 20 January $(\$ 4)$ it was at chairman Blåfield's suggestion decided that all councilmen can use either Swedish or Finnish, but that if they are not able to express themselves in both languages (i.e. to self-interpret), interpreting will be provided by volunteer members of the council. This practice clearly supported bilingual delivery.

It was further decided that the minutes be kept in Swedish only but that decisions will be written in both Swedish and Finnish (i.e. translated into Finnish by Secretary Jernberg who was also responsible for drafting the minutes in Swedish). This limited translation was considered the best combination of 'economy and justice'. The reference to justice is noteworthy as it signals a language ideological move away from (German) Romantic nationalism and towards the rising (Anglo-Saxon) social radicalism and consequently towards seeing language less as a cultural question than as a pressing social issue (Engman 1995: 187). In other words, the argument for translation is not based on using Finnish because of being in Finland in the spirit of a one nation, one language 
ideology, but on using Finnish so that the Finnish-speaking lower-class majority can understand and participate. To summarize, the first policy was supportive of bilingual practices, relying on self-translation and volunteer interpreting. In a combination of pragmatism and idealism, the councilmen accepted the existing difficulty of pushing Finnish to a prominent position, but many of them were willing to take personal initiative to support its entry into this domain of use by volunteering to translator and interpreter roles (Koskinen 2017).

Tampereen Sanomat reported the decisions without comment (e.g. TS 26.1.1875). This pragmatic ideology of rehearsing the language to increase its expressive force and repertoire was, however, clearly shared by the paper. For example, in a lengthy commentary titled 'On Finnish protocols in district courts?' the readers were encouraged to exercise their right to demand documents in Finnish in accordance to the language act of 1863 :

Luulemme jokaisen järki-ihmisen ymmärtävän, että tärkeän kielimuutoksen menestys riippuu tykkänään siitä, että jokainen oikeutta käyvä asetuksen määräämäin rajain sisällä vaatii suomenkielisiä protokollia - sillä ainoastaan sen kautta suomenkielisiä protokollia todellakin ilmestyy, ainoastaan sen kautta tuomarit harjaantuvat kielemme käyttämiseen ja ainoastaan sen kautta vihdoin itse kielikin taipuu ja muodostuu mukavaksi välikappaleeksi. (TS 23.2.1875) ${ }^{4}$

This issue of language use in juridical processes comes up repeatedly in Tampereen Sanomat. The language decree issued in 1863 had allowed for a twenty years' transition period to set up a system of also producing official documentation in Finnish. The transition period was needed, as in the midnineteenth-century Finnish was still quite underdeveloped, and the 1870s is often considered as a watershed period in the path to modern Finnish (Engman 1995: 188). In 1875 the end of this period was drawing closer, and institutional pressure to conform to the new requirements was increasing. Media attention contributed to mounting expectations. In an opinion piece, author L-ko points to the translatorial nature of the Swedish protocols in an ironic style and with three exclamation marks:

Asian oudon mielestä, luulisi olevan päivää selvemmän, näet kuin on suomalainen lautakunta, suomenkielellä tutkitaan todistajat samaa kieltä enimmästi - puhuvat riita kumpanit [sic] j.e.p., niis oudon mielestä on vaikeaa että kääntää pöytäkirjalle asian toiselle kielelle. Vaan itse hyvät herrat asian parhaiten tietävät!!! (TS 6.10. 1874)5

Announcements are an interesting subgenre of newspapers, and official announcements are one window to daily language practices. Since Tampereen 
Sanomat was in 1875 the only local newspaper, it was also the official channel for municipal institutional communications, and in this year these were published bilingually. Among these were invitations to council meetings, always in both Finnish and Swedish. This was nicely in line with the explicit language policy and translation decisions made in the council. The announcements of the public readings of the previous meeting's minutes at the court hall, in turn, were published only in Finnish which indicates that the reading may also have taken place only in Finnish, in sight translation mode as the minutes were written in Swedish.

A more unexpected finding from the point of view of established language policy was the micro-cracks in the image of the magistrate, which has been pictured as the bastion of Swedish language in the municipal scene both by contemporaries and in history books. I was therefore surprised to find in the issue of 20 April 1875, for example, four announcements officially signed by Mayor Procopé (known as an ardent defender of Swedish) and published only in Finnish, whereas only one announcement was published in Swedish. One of the announcements in Finnish only was furthermore directed at the councilmen, who themselves had agreed on a bilingual policy that foregrounded Swedish over Finnish, and who published their own announcements bilingually.

\subsection{Institutionalization of Finnish (1878)}

The council had started its operations in 1875 in a consensus-seeking atmosphere, but tensions soon began to rise both nationally and locally. On 9 January 1878 the council reopened its decision from 1875 at the initiative of Gustav Selin, a local businessman and a fierce Fennoman (Koskinen forthcoming). The new decision ( $\$ 12$ ) overturned the balance of the two languages 'until otherwise perhaps ordered': Finnish now became the language of the minutes, and only decisions were to be translated into Swedish. The minutes of 9 January follow this new policy, being kept in Finnish. Tampereen Sanomat duly reports this as all other decisions in the meeting (TS 22.1.1878), but the matter is stated briefly and without commentary.

From some other content in the paper one can see that its language policy was changing in pace with the council. In 1875, Tampereen Sanomat had adopted the policy of bilingual announcements. Now it has shifted its policy back towards Finnish only, and issued an editorial statement (signed U.T.) that went in line with the new council policy and was probably affected by it:

Kumpika kieli, suomi vai ruotsi on Tampereella yleisempi? Suomi, sillä umpiruotsalaisia on vaan kymmenkunta. Kummalla kielellä olisivat kuulutukset 
ja ilmoitukset julkaistavat Tamp- S:issa? Tietysti ainoastaan suomeksi; yksityiset tehkööt kuitenkin niin kuin tahtovat, mutta kaupungin yleiset kuulutukset ainoastaan suomeksi. ${ }^{6}$

It is noteworthy that the difference between public and private announcements, that is, institutional and non-institutional communication, was clearly demarcated, and a different policy line was proposed for each. To facilitate the favoured policy, the paper also adopted practical measures: in the previous issue the paper offered translation services for those who needed help in providing their announcements in Finnish.

The final sentence of the piece is explicitly conciliatory: 'Tätä ei ole kirjoitettu kielikiistan halusta' (This has not been written to provoke the language strife). The paper, still the only one in town and also tied to its role as the official information channel, may have wanted to emphasize its peacefulness, but it also seems clear that the language attitudes had become more radical. The following provocative opinion piece was published with an innocent-looking title 'Proposal':

Yksinkertaisin ja helpoin tapa maalin saavuttamisessa olisi kieltää kaikkia, jotka oleksivat kaupungissa ja sen lähistöllä puhumasta ruotsia ja lukemasta mitään tällä kielellä, vaan se olisi kohtuutonta suurta ihmispaljoutta vastaan ...] Mutta kun seurakunnalla on vapaus kieltää vähemmän tunnettujen henkilöiden kuntaan tulemasta, ehdottaisimme että seurakunta tästälähin kieltäisi ottamasta sellaisia henkilöitä, jotka ainoastaan puhuvat ruotsia. Useita vuosia kuluisi ... vaan sen kautta loppuisi kielikiista ja suomalainen asia edistyisi; eikä myöskään sellaisesta päätöksestä muitaakaan vieraita kieliä puhuvain henkilöiden harrastukset tulisi loukatuiksi. (TS 2.4.1878, no 13) ${ }^{7}$

The tone of the text is reminiscent of today's social media discussions on migration, with one significant difference: the writers of this text wanted to make explicitly clear that they did not object to any other foreign languages and they had no issue with other people coming in. It was only Swedish that was seen as threatening. In Section 5.1, I mentioned the changing ideology from nationalistic to social argumentation in the council a few years earlier. This kind of discourse is a reminder that different ideologies can coexist, and the same language attitude - and language policy - may be a result of different paths of reasoning.

\subsection{Turmoil (1881)}

In 1878 the pressure was already mounting in the language issue. Three years later the tensions were even higher, both at national level and in Tampere. In 
early 1881, one nexus of the language debates was the municipal chamber of finance, a new institution created in 1873 in the same degree as city councils but placed under the auspices of the magistrate's office. Officially, it had minimal independent powers; in practice, it became the executive committee of the council (Rasila 1984: 443). In Tampere, its position between the increasingly Finnish-speaking council and the Swedish-speaking magistrate put the chamber of finance's language policy to the spotlight. On 5 February 1881, Tampereen Sanomat took an active language political role in pushing its desired solution in advance to it being taken up in the next council meeting. The close connections between the paper and some of the councilmen were always known, but the council issues and language decisions had earlier been reported neutrally and only after meetings, whereas the more fervent language attitudes were expressed in other texts. This time the paper anticipated the upcoming council meeting of 9 February, when the item of the chamber of finance's language of communication with the council was to be on the agenda. The paper provided background and rationale, seeing the development as a logical continuation from the council decision made in 1878 and evoked the idea of officials gaining practice in writing in Finnish as the transition period set in the 1863 language act was coming to an end (TS 5.2.1881).

The council meeting was not, in spite of the moral support from Tampereen sanomat, smooth sailing. Gustaf Selin once again acted as the initiator, proposing that Finnish should be made the official language of the chamber of finance. The case was debated, but after the vote (11-18), the council cautiously decided that it was not clear whether it had jurisdiction over the matter, and that it would only express a recommendation. After the meeting (TS 12.2.1881) the paper published a clearly upset report on the 'lengthy quarrel', painting Reverend Tallqvist as the villain of the story, both for raising dubious legal aspects to begin with and for doing this 'naturally only in Swedish' Jernberg, in turn, was pictured as an avid advocate of the cause of Finnish.

Attitudes became increasingly divided in May 1881, when the seventy-fifth birthday of Johan Vilhelm Snellman was celebrated across the country (Rasila 1984: 548). Snellman was a Swedish-speaking statesman, professor, publisher and language activist, who had been influential in the language strife. In his numerous publications (in Swedish) he had laid the ground for the Finnish nation and forwarded the case of Finnish. In 1881, his birthday offered a perfect opportunity for Fennomans to push their agenda forward. Tampereen Sanomat published a long text that not only reported the festivities but also participated in building social tension against the ruling class, pitching it against the Finnish- 
speaking '7/8 of the population' (TS. 25.5.1881). It started by commenting how for the first thirty-five years of the Grand-Duchy the officials had 'been able to sleep soundly after dinner, to sit their evenings playing cards and drinking up their hot toddies while the priests made sure that the jolly peasants were given an odd prayer book for consolation'. As teetotalism was high on the political agenda, and playing cards was considered sinful by many, the depiction clearly aimed to discredit the Swedish-speaking governors. The mention of the odd prayer book in the citation refers to a severe lack of books in Finnish in the first half of the nineteenth century, and the fact that the available reading material had mostly consisted of religious materials, whereas 'on natural sciences only one booklet' was available. To remind the readers of how bad the situation had been, the text then moved to the issue of official languages and to complaining how officials of all ranks used to be Swedish-speaking, and how they had required all paperwork to be in Swedish.

In May the legal context changed. On 9 May 1881 the new emperor Alexander III issued a declaration concerning the institutional language use in courts and in governance, supporting the case of Finnish. On 28 May 1881 (and later again in 7 January 1882) it was published in Tampereen Sanomat in full. The manifesto reinforced the 1863 decree and anticipated the end of the transition period by emphasizing that the courts and governing institutions have the power to issue documents in Finnish if that was the language first used by the person who first raised the issue even without explicitly being asked to do so. The practical difficulties potentially created by this policy of using a less than fully developed language of institutional communication were acknowledged by adding the proviso that when an ad hoc word was resorted to and the word in Finnish was not widely known, the intended meaning was to be given by a Swedish expression in brackets.

Rising awareness of linguistic rights among Finns created tensions and led to a de facto two party system also at the local level, as politically active men became organized around either the Finnish or the Swedish language (Rasila 1984: 570). It turned out, however, that voters were less polemical than the public debates might lead us to believe, and the two nominees elected with the highest number of votes in 1881 (senior councilmen Frans Sumelius and Otto Blåfield) were both listed as candidates on both sides. All in all, the election was a triumph for the Finnish side: from the ten seats that were filled (each year onethird of the seats was open for re-election), five were secured by the Fennoman side; two more went to Blåfield and Sumelius who were favourable to the cause, and the Swedish party only got three seats (ibid.) 
Towards the end of the year increasingly heated discussions led to two new newspaper projects. In January 1882 the first issue of Aamulehti was published. Rasila (1984: 547) argues that it was founded because many Fennomans felt that Tampereen Sanomat lacked language political edge. Aamulehti was expected to be more radical in its approach. The first issue (AL 4.1.1882) reports that a complaint had already been filed against the new paper for Fennophile agitation. The paper denied the allegation, arguing that this could not be the case as half of the journalistic staff had previously worked in 'the patriotic Tampereen Sanomat'. A likely scenario is that these journalists were among those who felt the policy line adopted by Tampereen Sanomat was too moderate.

The aftermath of year 1881 in general, and the founding of Aamulehti in particular, also led to the establishment of a Swedish-speaking counterforce, Tammerfors Aftonblad later in 1882. It functioned as a symbol of the re-enforced Swedish identity of a small minority surrounded by a (locally) major language that was gaining prominence at a time when the situation where the minority made the decisions on behalf of the majority (Lönnroth 2009: 125) was becoming increasingly untenable. In the inaugural issue (TA 3.6.1882) the mission of the new paper was described as serving the needs of those who do not read Finnish fluently (implying the widespread bilinguality of the intended readership), and the language policy line was defined as 'impartial' and aiming to avoid 'the unfortunate newspaper polemics' of the Finnish-speaking press, 'which most of the reading public consider upsetting rather than constructive. This selfproclaimed non-partisan voice of reason was repeated in numerous issues of the paper where Fennoman positions were reported in reproaching tones that reflected an assumed moral high ground. This attitude no doubt aggravated the conflict. Lönnroth's interpretation of the policy line is more positive; he sees it an indication of tolerant attitudes among Swedish-speakers (2009: 145-7; cf. 163). Indeed, apparently tolerant attitudes towards the Finnish language were also given space in the paper, but paternalism is explicit. The lead article portrays the Finnish peasant as a noble savage, and identifies the Finns' poor skills in foreign languages as the root cause for language issues in governance (TA 30.6.1882).

\subsection{Final Challenge (1886)}

Year 1881 had been a watershed in the language strife, both in terms of sharpening attitudes and in terms of media visibility. The new outlets on both sides of the language barrier provided new opportunities for debates and public commentary. A further complication came from the increased efforts of 
Russification towards the end of the 1880s, with intensified efforts in promoting the Russian language. Success was meagre. In practice the effort mainly led to favouring Finnish over Swedish. A new decree reinforcing the use of Finnish in courts and offices was issued. The transition period set in the 1860s had come to an end, and from the beginning of 1882 onwards, newly appointed officials had to master both Swedish and Finnish. One might have also expected to find the local language policy in Tampere settling for a harmonious coexistence of the two languages. In practice, things went in the opposite direction. In May 1882 the council non-ceremonially simply dropped the Swedish translations of decisions in the minutes.

Tensions that had developed in 1881 were also kindled in the media. It seems clear that the founding of two new newspapers, one on both sides of the strife, hardened attitudes and created media bubbles reminiscent of today's social media, allowing each side to develop a sense of right-mindedness and painting the other side in negative colours. An interesting detail is the label 'vikings' in the media data used to refer to Svecomans. A search with (viikinki OR viking) reveals that this label was first used in Aamulehti in 1882. In total, there are 101 hits in the three newspapers across the period under study (only a couple of times referring to the actual Viking times, and once to a ship named Viking). Throughout this time, the usage in Finnish papers has clear negative connotations. The hits in Tammerfors Aftonblad, however, reveal an interesting pattern: they first emerge in upset recounts of what has been said elsewhere but towards the end of the period begin to be used in a fairly neutral way to indicate identity. The label was not Aamulehti's own innovation though, and its origin is on a racially motivated nationalistic and radical movement inside the Svecomans, centred around the journal Vikingar (1870-4). In other words, the original connotations were definitely meant to be positive. The Tampere use patterns seem to deviate from the capital-centred discourse in ways that would merit an analysis in itself. The main observation for our current purposes is in the ways in which also this label was used to promote antagonistic attitudes on both sides.

The community around Tammerfors Aftonblad and the founding of a 'conversation club' for Swedish-speakers in Tampere in 1885 (following the establishment of a similar club for Finns in 1882) seem to have given a new sense of momentum for the Tampere Svecomans, and in 1886 the issue of council languages was revisited. In March, councilman Mörtengren raised the issue of returning to translating decisions and voting proposals into Swedish. The item was tabled (minutes 3.3.1886, $\$ 63$ ), but the council returned to it in its next 
meeting in April. Referring back to the decision on 1878 that had never been explicitly overturned, Mörtengren then demanded a return to a legal state of affairs (minutes 7.4.1886, $\$ 85$ ). The council continued discussion in its meeting in May. Tampereen Sanomat reported the council debate in detail, foregrounding the role Mr Jernberg and citing his arguments of the changed legal situation (after the decree of 1883) at length. Of interest here is also Jernberg's interpretation that since the decree talks about 'language', and not 'languages', returning to bilingualism is out of the question (TS 22.5.1886).

I had earlier also gone through the council correspondence during 1875 and found that while the council wanted to actively promote Finnish, the inhabitants who wanted to advance their case in the municipal administration expected Swedish to help their case, and the great majority of the incoming correspondence was drafted in Swedish. In 1886, the language attitudes had changed, and the majority of the letters were now in Finnish, but approximately one-third was still in Swedish. An interesting detail is that when Otto Blåfield approached the council in his town doctor capacity, in 1886 he did so in Swedish, whereas in 1875 he had been instrumental in establishing Finnish as a language of governance, also through his own language choices. The ideology of bilingualism that he had consistently forwarded had helped push Finnish forward, but it was in 1886 a minority position, as local governance and language attitudes were moving towards monolingualism.

After discussion, debate and preparatory work, the council voted for legalizing the current practice, and so Swedish was voted out from the protocols, although it was still used orally. Throughout the lengthy decision process, Tampereen Sanomat and Tammerfors Aftonblad took an active part. Tampereen Sanomat argued for the Finnishness of Tampere and painted the suggestion of also adding Swedish as unreasonable (TS 17.4.1886). Tammerfors Aftonblad, in contrast, saw it as a sensible and pragmatic practice that is 'so economical and so just' that is should have been accepted without any further ado (TA 12.3.1886). Tammerfors Aftonblad also argued that the few monolingual Swedish-speakers in Tampere were 'surely the ones in whose pockets the council will mainly dig into' (TA 12.3.1886), an argument the Finnish-speaking side found offensive, emphasizing democratic language rights for the people. Tammerfors Aftonblad took a superficially moderate tone, but its paternalistic style must have been difficult to swallow on the Fennoman side. For example, on 26 March, the paper commented on national and local language efforts to put Finnish forward as follows:

Men den bildade och politiskt mogna opinionen i landet - och lyckligtvis finnes ännu en sådan - har allt skäl att djupt beklaga den förhastade åtgjärden, 
framkallad som den är af någre okloke skrikhalsar, hvilka, ställande ernåendet af föremålet för sitt barnsliga kältande högre än allt annat, med en politisk lättfärdighet som med sårighet söker sin like, spelat hazard om fosterlandets dyrbaraste intressen. ${ }^{8}$

The two papers also debated with each other, reporting on what the other had said and refuting the claims in varying degrees of moral outrage (see, for example, TS 20.2.1886 and 3.4.1886). On a couple of occasions (20.2.1886; 16.3.1886) Tampereen Sanomat complained about a clumsy and erroneous translation of its article in Tammerfors Aftonblad, but all in all there is a curious absence of any critique towards the Finnish translations in the media and also in council discussions. It seems as if the status of Finnish was too fragile to unsettle by criticism.

In 1886, the Fennophile movement was at its height in Tampere, but also new divisions were emerging, allowing the Svecoman side to regain power. In the election, the two Fennoman sects that were formed at the national level were now debating between themselves, and also the two local Finnish newspapers were divided (TU liberal, AL more conservative). As divisions emerged around new topics, language was no longer necessarily seen as a primary issue, although Aamulehti actively sought for compromises among Fennomans to block some Svecophile candidates (Rusila 1984: 571-2). Indeed, the election results were bad for Svecomans. The clear winner, then, was the cadre of businessmen, many of them Finnish by origin but fluently bilingual because of their professional background (Rasila 1984: 573). This, however, did not lead to a strengthening of bilingual practices. As if signalling the beginning of a new era for the council, Otto Blåfield was no longer running for office (and died later in the same year). He had systematically supported the use of both languages in the council, but attitudes among Finnish-speakers were no longer supportive of bilingualism. Aamulehti (26.9.1886; see also AL 11.3.1886) depicted the idea of forcing a representative body of an entirely Finnish ('umpisuomalainen'; emphatic) town to use 'mixed languages' ('sekakielinen'; a pejorative term) as ludicrous, and said that those 'ten or so' men who live in Tampere without bothering to learn the local language and 'bragging about their ignorance' are an exception not to be listened to. In the light of this it is interesting to note that the practice of 'oral translation' (by the secretary) is mentioned in passing as an ongoing practical solution (TS 3.4.1886; 16.3.1886; TA 12.3.1886). The debate only concerns the written official documentation of the meetings.

In the new elections for the 1887 council held at the end of 1886 voting numbers were higher than before. However, for a number of Finnish-speakers 
language had ceased being a primary concern and that the internal division of the Fennoman side had become increasingly pronounced. One day before the election, Aamulehti reminded Finnish-speaking voters that the Svecomans will surely 'vote as one man', and warned that a failure to do the same on the Finnish side will lead to a Svecoman victory, which in turn will allow them to 'change the council into Svecoman, both in spirit and in language' (AL 2.12.1886). In spite of Aamulehti's campaign the voting results showed that some influential Finnishspeakers had indeed favoured Swedish-speaking candidates. Tampereen Sanomat (TS 31.12.1886) commented with shock, disappointment and worry, foreseeing an increasingly Swedish-speaking administration. The gloomy prognosis did not materialize. On the contrary. Although the local power balance was shifting towards Swedish, language planning efforts at national level had created a legal framework that gave Finnish strong support, and it was becoming evident that Swedish was fighting a losing battle. Indeed, also in Tampere the new normal (i.e. Finnish only) was gradually accepted, and in 1887 the debate began to die out. In the 1887 election language was no longer seen as a decisive dividing factor.

\section{Conclusion}

Between 1875 and 1886 the council language policy evolved, through numerous translatorial turns, from monolingual Swedish to monolingual Finnish. The three interrelated levels of language policy - planning, practices and attitudes - contributed to this development in multiple ways. Generally, it is easy to accept the idea that a language policy brings forward some translation practices. This chapter, however, examines the opposite direction of causal emplotment: how the use of particular translatorial strategies at the micro-level can be seen to actively push forward particular language policies, and how debates over language hierarchies and translation practices can be seen to both reflect and fuel the conflicting language attitudes of the time.

The dense points discussed in this chapter, and their three different data sets, allow us to zoom into the constantly evolving language planning at national level, the changing language and translation decisions at local level and the surrounding climate of language ideologies and attitudes. Of these three levels the nationwide language planning activities provide a legal framework that the local environment adapts to but has few possibilities to actively influence. In contrast, the council practices and media debates are intertwined, and the media has an active language policy role. 
The case of the Tampere city council shows that translation is not only a reaction to an existing linguistic context but also a tool for actively shaping that context. Translation is often seen as a benevolent activity, in service of more participatory governance through multilingualism. This case unsettles that assumption by showing that translation can also be used as a scaffolding device, to help an underdog language move gradually into a dominant position. At first, introducing translation enabled bilingual practices; a few years later language rights for minorities were no longer seen as a valid argument, and those in favour of bilingualism fought a losing battle. Putting translation in the service of Finnish was not only a language choice but also tied to a number of other societal aims such as workers' rights, democratization and the gradual development of a civil society. Language issue was also a platform for training party politics, and as the political map developed, other kinds of divisions became more central.

\section{Notes}

1 On the gradual development of Finland as a nation see, for example, Engman (1995).

2 The Finlayson cotton mill was a major employer at the time, and the lucrative employment possibilities also drastically increased the number of young women in the population, tilting the demographics of Tampere towards an over-representation of (unmarried) women in all age groups between 15 and 40, and earning it the nickname of 'Cotton girls' town' (Rasila 1984: 244).

3 Railway network that was also being built at the time was also essential for the dissemination of news; Tampere was connected to Helsinki and Turku by rail in 1876.

4 'Any sensible person will surely understand that the success of a significant language change is entirely dependent on everyone who is engaged in juridical matters demanding, within the limits of the statute, protocols to be provided in Finnish - it is the only way to ensure that Finnish protocols will begin to be published, the only way to ensure judges will gain practice in using our language and the only way through which the language itself will bend and mould into a comfortable tool.'

5 'To the uninitiated it would appear to be clearer than day that when you have a Finnish jury, examination in Finnish, witnesses in Finnish and - mostly - Finnishspeaking adversaries and so on, so the uninitiated would think that it is difficult to translate the issue into another language in the protocol. But of course the good gentlemen themselves know best!!!

6 'Which language, Finnish or Swedish, is more common in Tampere? Finnish, as there are only a dozen of monolingual Swedes. In which language should 
announcements and notices be published in Tampereen Sanomat? Only in Finnish, of course; private businesses can still do as they see fit, but the official municipal announcements only in Finnish.' (TS 12.3.1878)

7 'The simplest and easiest way to reach the goal would be to forbid anyone who resides in this town or in its vicinity from speaking Swedish or from reading anything in this language, but this would be unreasonable for many people ... But as the parish has the right to forbid any unknown person from entering the town, we propose that from now on it would refrain from accepting any persons who only speak Swedish from moving in. Many years would pass ... but this would end the language strait and the case of Finnish would make progress; and this decision would not hinder or hurt the endeavours of those speaking other foreign languages.'

8 But an educated and politically mature opinion in this country - and luckily there still exists one - has every reason to deeply regret the hasty measures called forth by some not too clever bawlers who, putting their childish aims above anything else, have hazarded fatherland's most valuable interests with political flightiness an equal of which is hard to find.'

\section{References}

\section{Primary sources}

Kielireskripti [rescript on language]. Keisarillisen Majesteetin Armollinen Asetus Suomen kielen asettamisesta yhdenmoisiin oikeuksiin Ruotsin kielen kanssa kaikissa semmoisissa kohdissa, jotka wälittömästi koskevat maan nimen-omaan suomalaista wäestöä. Suomen Suuriruhtinanmaan Asetus-Kokous 26/1863.

Kunnallisasetus [decree on local government]. Asetus kunnallishallituksesta kaupungissa. Suomen Suuriruhtinanmaan Asetus-Kokous, 40/1873.

Uusi Keisarillisen Majesteetin Armollinen Julistus, koskeva laajennettua oikeutta Suomen kielen käyttämiseen tuomio-istuimissa ja virastoissa Suomenmaassa. Annettu Helsingissä, 9 p:nä Toukokuuta 1881. [Emperor's declaration on the extended right to use Finnish in courts and offices in Finland. Helsinki, 9.5.1881]

Asetus Ruotsin ja suomen kielen käyttämisestä erinäisissä virastoissa ja tuomioistuimissa Suomen suuriruhtinaanmaassa. Annettu 29.12.1883.

Hänen Majesteettinsa Keisarin ja Suuriruhtinaan Armollinen Käskykirje Ruotsin ja Suomen kielten käyttämisestä asiain käsittelemisessä virkakunnissa ja virallisessa kirjeenvaihdossa. Suomen Suuriruhtinanmaan Asetus-Kokous 18.3.1886/11. (Julkiluettava saarnastuolista).Annettu Hatsinassa, 18 (6) p:nä Maaliskuuta 1886. [Emperor's rescript on using Finnish and Swedish in offices and in official correspondence. To be read out from pulpit. Hatsina, 18.3.1886.]

Keisarillisen Majesteetin Armollinen kirje Turun Hovioikeudelle, sisältävä tarkempia määräyksiä Suomen ja Ruotsin kielten käyttämisestä asioita virkakunnissa 
käsiteltäissä ja virallisessa kirjeenvaihdossa. Suomen Suuriruhtinanmaan AsetusKokous 4.4.1887/6. Annettu Helsingissä, 4 p:nä Huhtikuuta 1887. [Emperor's letter to the Turku court of appeal, containing further provisos on using Finnish and Swedish in offices and in official correspondence. Helsinki, 4.4.1887] Minutes of the Tampere city council 1875, 1878, 1881, 1886. Tampere city archive. Tampereen Uutiset, Aamulehti, Tammerfors Aftonblad: https://digi.kansalliskirjasto.fi/s anomalehti/ (accessed 27.9.2018)

\section{Secondary sources}

Cronin, Michael (2006), Translation and Identity, London and New York: Routledge. Engman, Max (1995), 'Finns and Swedes in Finland', in Sven Tägil (ed.), Ethnicity and Nation Building in the Nordic World, 179-216, Carbondale and Edwardsville: Southern Illinois UP.

Engman, Max (2009), Pitkät jäähyväiset. Suomi Ruotsin ja Venäjän välissä vuoden 1809 jälkeen [The Long Goodbye: Finland between Sweden and Russia after 1809]. Helsinki: WSOY.

Foucault, Michel (1978/2007), Security, Territory, Population. Lectures at the College de France 1977-1978, ed. M. Senellart, trans. G. Burcell, New York: Palgrave Macmillan.

Grin, Francois (2010), 'Translation and the Dynamics of Multilingualism', Cahier de recherche élf $n^{\circ} 3$. Université de Genève, Observatoire élf. Available online: http:// www.unige.ch/traduction-interpretation/recherches/groupes/elf/documents/elfwp3 .pdf

Koskinen, Kaisa (2014a), 'Institutional Translation: The Art of Governing by Translation', ed. Ji-Hae Kang, Translation in Institutions. Special issue of Perspectives, 22 (4): 479-92.

Koskinen, Kaisa (2014b), 'Tampere as a Translation Space, Translation Studies 7 (2): 186-202.

Koskinen, Kaisa (2017), 'Translatorial Action in Non-professional Translation Communities: The Tampere City Council in 1875', in Kristiina Taivalkoski-Shilov, Liisa Tiittula and Maarit Koponen (eds), Communities of Translation and Interpreting (VitaTraductiva), 37-61, Montreal: Éditions québécoises de l'oeuvre.

Koskinen, Kaisa (forthcoming), 'Translatorisuus dynaamisen kielipolitiikan välineenä Tampereen kunnallishallinnossa 1870-1880-luvuilla [Translatoriality as a Tool for Dynamic Language Policy in 19th Century Local Government in Tampere]', in Arja

AQ: Please update the reference 'Koskinen, forthcoming' Nurmi, Saija Isomaa and Päivi Pahta (eds), Kielten ja kulttuurien mosaiikki: Valta, periferia ja arki. Helsinki: SKS.

Lönnroth, Harry (2009), Svenskt i Tammerfors, Tampere: Tampere University Press. Meylaerts, Reine (2013), 'Multilingualism as a Challenge for Translation Studies', in Teoksessa Carmen Millán and Francesca Bartrina (eds), The Routledge Handbook of Translation Studies, 519-33, Routledge: London and New York. 
Paloposki, Outi (2007), 'Suomentaminen ja suomennokset 1800-luvulla' [Translating and Translations into Finnish during the Nineteenth Century], in H. K. Riikonen, Urpo Kovala, Pekka Kujamäki and Outi Paloposki (eds), Suomennoskirjallisuuden historia I [History of Translated Literature in Finland], 102-26, Helsinki: SKS.

Rasila, Viljo (1984), Tampereen historia II. 1840-luvulta vuoteen 1905 [History of Tampere II. 1840-1905], Tampere: The City of Tampere .

Spolsky, Bernard (2004), Language Policy, Cambridge: Cambridge University Press.

Vähäpesola, Johanna (2009a), 'Kaupunki 1870-1900', in Koskesta voimaa. Digital source of Tampere history. University of Tampere. Available online: http://www15.uta.fi/ koskivoimaa/kaupunki/1870-00/index.htm (accessed August 24, 2018).

Vähäpesola, Johanna (2009b), Äidinkieli, kansallisuus ja uskonto. Available online: http://www15.uta.fi/koskivoimaa/kaupunki/1870-00/kielijauskonto.htm (accessed August 24, 2018).

Vähäpesola, Johanna (2009c), Tampereen väestö 1870-1900. Available online: http: //www15.uta.fi/koskivoimaa/kaupunki/1870-00/vaesto.htm(accessed August 24, 2018).

Wolf, Michaela (2012), Die vielsprachige Seele Kakaniens. Übersetzen und Dolmetschen in der Habsburgermonarchie 1848 bis 1918, Wien \& Köln \& Weimar: Böhlau. 
